
\title{
25 Research Square \\ Spatiotemporal and Source Analysis of Ultrafine Particulates (PM1) Over Bengaluru, Karnataka, India
}

manjunatha AS ( $\square$ manjunathas@bmsce.ac.in )

BMS College of Engineering https://orcid.org/0000-0002-5428-186X

K E Ganesh

BMS College of Engineering

\section{Research}

Keywords: PM1, Morphology, Elemental composition, Scanning Electron microscope, anthropogenic activities

Posted Date: June 9th, 2020

DOI: https://doi.org/10.21203/rs.3.rs-32223/v1

License: (c) (i) This work is licensed under a Creative Commons Attribution 4.0 International License. Read Full License 


\section{Abstract}

Measurements and analysis of Particulate Matter of aerodynamic diameter $1 \mu \mathrm{m}\left(\mathrm{PM}_{1}\right)$ has been carried out using indigenously built air sampler APM 577from IIT-Kfor the study period July 2018- July 2019at the following locations of Bengaluru city: Basavanagudi (BAS), Domlur (DOM), Hosur road (HOS) and DC Halli (DCH). The mass concentration of collected $\mathrm{PM}_{1}$ sampleshas been observed to vary from 20.16 $\mu \mathrm{g} / \mathrm{m}^{3}$ to $68.64 \mu \mathrm{g} / \mathrm{m}^{3}$ during the studyperiod. The highest mass concentration of $68.64 \mu \mathrm{g} / \mathrm{m}^{3}$ was observed for the location BAS and the lowest mass concentration of $20.16 \mu \mathrm{g} / \mathrm{m}^{3}$ was observed for the location DOM. The average mass concentration of $\mathrm{PM}_{1}$ around Bengaluru for winter, summer, monsoon \& post monsoon season is observed to be $47.60 \mu \mathrm{g} / \mathrm{m}^{3}, 40.24 \mu \mathrm{g} / \mathrm{m}^{3}, 30.85 \mu \mathrm{g} / \mathrm{m}^{3}$ and 38.76 $\mu \mathrm{g} / \mathrm{m}^{3}$ respectively. The average $24 \mathrm{hrmass}$ concentrations of $\mathrm{PM}_{1}$ in winter season is found to be higher than National Ambient Air Quality Standards(NAAQS) limit of $60 \mu \mathrm{g} / \mathrm{m}^{3}$ for $\mathrm{PM}_{2.5}$. The SEM-EDAX techniques were used to understand morphology and elemental composition of $\mathrm{PM}_{1}$. SEM Imaging technique confirms the fact that in ambient air atmosphere near the study locations the source of $\mathrm{PM}_{1}$ is mainly from anthropogenic activities(primary) and natural (secondary) formation. Also,some of the collected samples showed the presence of microorganisms and biological particles such as bacillus. Elemental composition analysis made by EDAX technique showed the presence of non -metals such as Carbon, Oxygen, Nitrogen, Aluminium, Sulphur and potassium.

\section{Introduction}

Air pollution is caused due to very small liquid and solid particles suspended in the air and it constitute to Particulate Matter. Based on size, particulate matter is often divided into three main groups such as coarse fraction, fine fraction and ultrafine fraction. The coarse fraction

contains the larger particles with size ranging from $2.5 \mu \mathrm{m}$ to $10 \mu \mathrm{m}\left(\mathrm{PM}_{2.5}-\mathrm{PM}_{10}\right)$. The fine fraction contains the smaller particles with a size up to $2.5 \mu \mathrm{m}\left(\mathrm{PM}_{2.5}\right)$ and the particles in size smaller than $0.1 \mu \mathrm{m}$ are called ultrafine particles.

The atmospheric particulate matter originates mainly from traffic, industries (primary emission) or formed in the atmosphere through natural process from wear and tear of rock, volcanic activities, resuspension of road dust (secondary emission) by transformation of gaseous emissions Wilson et al 2002 [1]. The size and chemical composition of $\mathrm{PM}_{1}$ strongly influence on human health, visibility, ecosystem and cloud properties etc.

The $\mathrm{PM}_{1}$ in atmosphere leads to the common lung and pulmonary diseases in human beings Delfino et al 2005[2] and such disease leads to alteration in morphology and functions of the epithelial cells Ramgolam et al 2009[3].Physical (size and morphology) and chemical (composition) characterization atmospheric particles has received significant importance due to their effect on radiative and chemical properties. The detailed characterization of atmospheric particles provides useful information about their 
sources, atmospheric history, formation, reactivity, transport and removal of atmospheric chemical species Lu et al 2006 and Adachi et al 2010[4,5]. and also, chemical composition of $\mathrm{PM}_{1}$ plays a very important role in chemical characteristics and its effect on ecology and environment Marmur et al 2006 [6]. The surface area is predominating in particles of size less than $2.5 \mu \mathrm{m}$ whereas mass is predominating in coarse particles.

PM are strongly affected by meteorological parameters such as precipitation, mixing layer height, temperature, air mass origin and season Jacob et a/ 2009[7] and Spindler et a/2010[8]. Weather change is supposed to have direct and indirect effects on urban PM which in fact depends on sampling season, air mass origin and temperature Fransen et al 2012[9]. The higher levels of PM concentration were during the winter months due to more frequent temperature inversions in winter combined with lack of precipitation Aryal et al 2008 [10]

Atmospheric PM is from many sources and differed in terms of physical and chemical characteristics, effects on human health and the ecosystem, persistence in the atmosphere and the ability to react with each other pope et al 2006[11]. Hence in the study period it is quantitative to determine the concentrations, morphology and its elemental composition of collected sample in Bengaluru at BAS, HOS, DOM and DCH locations based on the traffic density

\section{Methods And Material 2.1 STUDY AREA}

Bengaluru is known as World's dynamic city and capital of Karnataka state which is located between $77^{\circ} 24^{\prime} \mathrm{E}-77^{\circ} 28^{\prime} \mathrm{E}$ and $12^{\circ} 46^{\prime} \mathrm{N}-13^{\circ} 11^{\prime} \mathrm{N}$. It is situated at a height of about 920 meters above Sea Level. It has a population of over ten million making it a megacity and the third most populous city and fifth most populous urban agglomeration in India. It is located in southern India on the Deccan Plateau. Because of the availability of resources, Bengaluru has become the prime location for everyone. According to latest vehicles statistics released from Regional Transport Office-RTO the total number of vehicles registered in 2016 is $61,12,897$ and in the year 2017 it is 68, 33,080(transport.karnataka.gov.in) [12]. Hence there is about $11.78 \%$ increase in total vehicles on Bengaluru roads which in turn adds on to the total particulate load in to the atmosphere.

The summer season in Bengaluru is from April to June, the temperature varies from $22^{\circ} \mathrm{C}$ to $33^{\circ} \mathrm{C}$ and the relative humidity $(\mathrm{RH})$ varies from $40-68 \%$. Winter season is from December to February, the temperature varies from $16^{\circ} \mathrm{C}$ to $28{ }^{\circ} \mathrm{C}$ and the relative humidity varies from $52-68 \%$. Monsoon season which starts from June to September, the temperature varies from $18{ }^{\circ} \mathrm{C}$ to $30^{\circ} \mathrm{C}$ and relative humidity varies from $70-80 \%$ and in post monsoon season which starts from October to November, the temperature varies from $19{ }^{\circ} \mathrm{C}$ to $28{ }^{\circ} \mathrm{C}$ and relative humidity varies from $88-97 \%$. 
The major contribution to air pollution in Bengaluru is vehicular traffic, Industries with micro, small, medium and large scale industries with 77407 units(http://dcmsme.gov.in) [13] such as plastic, aluminium smelters, iron fabricators, ceramics, pharmaceutical companies and as well as construction activities.

\subsection{EXPERIMENTAL PROTOCOL}

Sampling of $\mathrm{PM}_{1}$ was carried out on roof of a building in Bengaluru at four different locations such as BAS (12.94 latitude and 77.56 longitude), HOS (12.89 latitude and 77.64 longitude), DOM (12.95 latitude and 77.63 longitude) and DCH (12.89 latitude and 77.62 longitude) as shown in Fig. 1 over a period of one year to determine the mass concentration and source analysis of $\mathrm{PM}_{1}$ as these locations has high vehicular traffic as well as residential as suggested by Karnataka state pollution control board[14]. The sampling frequency was once in a month except during monsoon and pre monsoon season. In winter season and summer season sampling were have carried out two to three. The $\mathrm{PM}_{1}$ was collected on PolyTetraFluoroEthylene-PTFE filter paper provided and manufactured by Envirotech with diameter $47 \mathrm{~mm}$. The sampler is APM-577 indigenously built by Envirotech and IIT-KANPUR which is portable so that sampling can be carried out at different locations. The $\mathrm{PM}_{1}$ sample operates without any voltage fluctuation with the help critical orifice and the air flow rate is at $10 \mathrm{~L} / \mathrm{min}$. The air inlet section has circular symmetry so that air entry is unaffected by wind direction, rain and insects etc. The inlet section immediately leads to impactor stage with a filter paper of $27 \mathrm{~mm}$ designed to trap particles size more than $1 \mu \mathrm{m}$. The fine particles of $\mathrm{PM}_{1}$ are collected on the PTFE filter paper for over a period of $24 \mathrm{Hr}$ and collected $\mathrm{PM}_{1}$ on filter paper was incubated for $24 \mathrm{Hr}$ with relative humidity of $35 \%$. Mass concentration was calculated gravimetrically by weighing the filter paper before and after sampling. Concentration of $\mathrm{PM}_{1}$ in ambient air is determined by mass of particulates(gm) on the filter paper in collected air

volume $\left(\mathrm{m}^{3}\right)$ for $24 \mathrm{Hr}$. Since the $\mathrm{PM}_{1}$ is small in size, a repeated measurement of filter paper will provide the accurate mass concentration of the $\mathrm{PM}_{1}$ in actual ambient air.

\subsection{SEM-EDAX}

$\mathrm{PM}_{1}$ samples were analysed by Scanning Electron Microscope (SEM)-Energy Dispersive Analysis X-ray (EDAX) TESCAN-VEGA3 at BMS college of engineering at Bengaluru. The SEM-EDX analysis was carried out with the help of computer-controlled field emission scanning electron microscope (SEM) equipped with an energy dispersive X-ray system (EDAX). The filter papers were cut in $1 \mathrm{~mm}^{2}$ from each sample. All the samples were mounted on plastic stubs for gold coating. A very thin film of gold (Au) was deposited on the surface of each sample using vacuum coating unit called Gold Sputter Coater to increase the electrically conductivity and which can prepare 6 samples at a time. The samples were placed in the corner of SEM-EDAX chamber. The working conditions were set at an accelerating voltage of $5 \mathrm{kV}$, a beam current of 1 pA to $2 \mu \mathrm{A}$ is passed. Images were taken at a magnification of X2000, X5000, X10000 and X20000

\subsection{MICRO-ORGANISM ANALYSIS}


The collected samples of $\mathrm{PM}_{1}$ were used to study the presence of microorganism using Lysogeny broth (LB)- Agar procured by Sigma- Aldrich which acts as a growth medium. The LB-Agar powder of $37 \mathrm{~g}$ contains $5 \mathrm{~g}$ of peptone, $10 \mathrm{~g}$ of peptone from casein, $10 \mathrm{~g}$ of Sodium Chloride and $12 \mathrm{~g}$ of Agar-Agar. The medium of LB-Agar was prepared using $8.14 \mathrm{~g}$ pre mixed powder of LB- Agar and a $500 \mathrm{ml}$ of sterile water was added it to make it $200 \mathrm{ml}$ of LB-agar medium. The gel was now placed for autoclave at $121^{\circ} \mathrm{C}$ under 30psi for $30 \mathrm{~min}$. High pressure used to prevent the gel mix from boiling over high temperature.

\subsection{METEOROLOGICAL STATUS OF BENGALURU}

The meteorological parameters such as atmospheric temperature, wind speed, wind direction and relative humidity plays a vital role in changing the concentration of particulate matter in the atmosphere. The average temperature, wind speed, wind direction and relative humidity over Bengaluru during study period July 2018 to July 2019 is shown in Table 1.

Table 1

meteorological data over Bengaluru during the period

\begin{tabular}{|llll|}
\hline Month & Temperature $^{\circ} \mathrm{C}$ & Wind Speed $\mathrm{km} / \mathrm{hr}$ & Relative Humidity \% \\
\hline July & 24 & 10.5 & 63 \\
\hline Aug & 23.6 & 9.3 & 88 \\
\hline Nov & 23.7 & 4.7 & 97 \\
\hline Dec & 23.2 & 4.3 & 88 \\
\hline Jan & 22.2 & 5.1 & 51 \\
\hline Feb & 25 & 5.1 & 56 \\
\hline Mar & 28.3 & 4.0 & 55 \\
\hline Apr & 29.4 & 2.8 & 54 \\
\hline May & 32 & 3.2 & 74 \\
\hline June & 30 & 7.1 & 94 \\
\hline July & 29 & 8.4 & 97 \\
\hline
\end{tabular}


Table 2

shows the mass concentration and elemental composition of each sampling during study period

\begin{tabular}{|lll|}
\hline Month & Mass concentration $\mu \mathrm{g} / \mathrm{m}^{3}$ & Elemental composition \\
\hline July & 50.87 & $\mathrm{C}$ and O \\
\hline August & 27.7 & $\mathrm{C}, \mathrm{O}$ and P \\
\hline $\begin{array}{l}\text { November } \\
\text { (2 sampling) }\end{array}$ & 31.21 and 46.31 & $\mathrm{C}, \mathrm{N}, \mathrm{O}, \mathrm{Al}, \mathrm{S}$ and K \\
\hline $\begin{array}{l}\text { December } \\
\text { (3 sampling) }\end{array}$ & $68.64,67.77$ and 46.36 & $\mathrm{C}, \mathrm{N}, \mathrm{O}, \mathrm{S}$ and P \\
\hline $\begin{array}{l}\text { January19 } \\
\text { (3 sampling) }\end{array}$ & $38.35,42.28$ and 43.19 & $\mathrm{C}, \mathrm{N}, \mathrm{O}, \mathrm{S}, \mathrm{P}, \mathrm{Na}, \mathrm{Cl}$ and K \\
\hline February & 26.75 & \\
\hline March & 40.540 & $\mathrm{C}, \mathrm{N}, \mathrm{O}, \mathrm{Si}, \mathrm{P}$ and S \\
\hline April & 53.52 & $\mathrm{C}, \mathrm{N}$ and O \\
\hline May & 33.605 and 33.33 & $\mathrm{C}, \mathrm{N}, \mathrm{O}, \mathrm{Si}, \mathrm{P}, \mathrm{S}, \mathrm{Na}, \mathrm{Cl}$ and Ca \\
\hline (2 sampling) & & $\mathrm{C}, \mathrm{O}$ and S \\
\hline $\begin{array}{l}\text { June } \\
\text { (2 sampling) }\end{array}$ & 20.1 and 34.489 & $\mathrm{C}, \mathrm{N}, \mathrm{O}, \mathrm{Na}$ and S \\
\hline July & 27.021 & $\mathrm{C}, \mathrm{O}, \mathrm{Al}$ and S \\
\hline
\end{tabular}

\section{Results And Discussion}

\subsection{Mass concentration analysis}

The $\mathrm{PM}_{1}$ mass concentration has been measured for $24 \mathrm{Hr}$ during the study period of July 2018 to July 2019 at four different locations of Bengaluru city as mentioned above. A total of 18 samplings has been carried out in the study period. The mass concentration values found to vary from $21.27 \mu \mathrm{g} / \mathrm{m}^{3}$ $68.64 \mu \mathrm{g} / \mathrm{m}^{3}$. The average mass concentration in winter, summer, monsoon and post monsoon seasons were observed to $47.62 \mu \mathrm{g} / \mathrm{m}^{3}, 40.25 \mu \mathrm{g} / \mathrm{m}^{3}, 32.05 \mu \mathrm{g} / \mathrm{m}^{3}$ and $38.76 \mu \mathrm{g} / \mathrm{m}^{3}$ respectively. The lowest mass concentration of $20.16 \mu \mathrm{g} / \mathrm{m}^{3}$ was observed in the months of June 2019 which is monsoon season and highest mass concentration of $68.64 \mu \mathrm{g} / \mathrm{m}^{3}$ was observed in December 2018 which is winter. This observed mass concentration of $\mathrm{PM}_{1}$ during winter season was consequently higher than $\mathrm{PM}_{2.5}$ NAAQS $24 \mathrm{Hr}$ standard limit of $60 \mu \mathrm{g} / \mathrm{m}^{3}$ (data.gov.in) [15]. The observed mass concentration is compared with 
$\mathrm{PM}_{2.5}$ NAAQS $24 \mathrm{Hr}$ standard limit since $\mathrm{PM}_{1}$ limit value not been legislated as stated in E Koulouri et al 2008[16]. The lower concentration observed in monsoon is due to washout of the particulates and highest concentration observed in winter is may be due to temperature inversion in ambient air. The dependence of $\mathrm{PM}_{1}$ mass concentration with temperature, $\mathrm{RH}$ and wind speed is shown in Fig. 2. The mass concentration with temperature and wind speed shows a negative correlation. The negative correlation between mass concentration and temperature is because of ventilation of particulates outside the atmosphere due to breaking of aerosol layer with increase in temperature as a result of sunrise. Also, it has been observed that mass concentration with relative humidity $\mathrm{RH}$ follows almost similar trend on some days and opposite trend on other days of sampling. Increase in mass concentration with $\mathrm{RH}$ indicates stacking up of particulates one above the other up to a certain threshold height which gives positive correlation. Once this growth exceeds a threshold limit then due to gravity settling the particulate growth breaks. Hence this shows opposite trend between mass concentration and $\mathrm{RH}$ as suggested by GE Shaw 1976[17].

\subsection{Morphological analysis of $\mathrm{PM}_{1}$}

The PTFE filter paper used for the collection of $\mathrm{PM}_{1}$ samples has been used for the morphological study with the help of Scanning Electron Microscope (SEM). SEM image gives specific source of $\mathrm{PM}_{1}$ whether it is due to primary formation or secondary formation Mirjana et al 2006[18]. As suggested by Atar Singh et al 2014[19], Energy Dispersive X-ray spectroscopy (EDAX) which gives the elemental composition of $\mathrm{PM}_{1}$ is also used in the present study.

The SEM image morphology for the location BAS Fig. 3.a shows that the particulates are spherical and irregular in shape with a mix of smooth and rough surface area. The elemental composition in $\mathrm{PM}_{1}$ is expressed in weight\% which indicates the relative concentration of the element in the sample. The elemental composition is Carbon, with 30.72 weight\%, and Oxygen with 1.21 weight\% respectively with small trace of Phosphorus.

The SEM image morphology for the location HOS Fig. 3.b. shows that particulates are spherical and irregular in shape with smooth and rough surface area and the elemental composition sampling site was Carbon, Oxygen with 29.89 weight \% and 1.65 weight \% respectively with small traces of Phosphorus.

The morphology of collected sample at location HOS during Diwali festival (5-6 November 2018) shows clearly that particulates have different morphologies. On 5th November 2018, the particulates were spherical and irregular in shape with smooth and rough surface area Fig. 4.a with elemental composition on the previous day of Diwali was Carbon 58.64 weight\%, Oxygen 28.77 weight \%, Nitrogen 11.66 weight\% and small traces of sulphur. Whereas on 6th November 2018, along with spherical and irregular shape, the particulates are observed to have plate like, rod like structures with smooth and rough surface area Fig. 4.b. with elemental composition of Carbon 50.30 weight\%, Oxygen 41.89 weight\%, Nitrogen 5.44 weight\% and small traces of Aluminium, sulphur and potassium. 
The morphology of collected sample in location BAS in december month Fig. 5. a. shows that collected Particulate during sampling were irregular in shape and rough surface area and some of them were biological particles Mirjana et. al2006[18] and the elemental composition was found to be Carbon 46.81 weight $\%$, Nitrogen 17.88 weight $\%$, Oxygen 34.25 weight $\%$ and small traces of sulphur.

The morphology collected sample at HOS location in december Fig. 5.b. shows spherical shaped particulates with smooth surface and rough surface area with rod shaped particulates which may be Bacillus pumilus as observed in Flavien Pillet et al 2006 [20] and the elemental composition in was Carbon 56.17 weight\%, Nitrogen 12.09 weight\%, Oxygen 30.92 weight\% and small traces of Potassium and Sulphur.

The samplings were carried out in December and January month respectively at DOM location and on both days sampling the particulates are irregular in shape with rough surface area Fig. 6. a.-6. b. The elemental composition during these two sampling were Carbon 56.85 weight\%, Nitrogen 15.31 weight\%, Oxygen 26.98 weight\% and with small traces of Sulphur and Potassium and Carbon 52.36 weight\%, Nitrogen 19.81 weight\%, Oxygen 27 weight\% and with small traces of Sulphur and Potassium respectively.

In the month of January two samplings were carried at BAS location and morphological analysis of one sample shows that particulates were irregular in shape and rough surface area Fig. 7.a. and the elemental composition was Carbon 50.93 weight\%, Nitrogen 13.32 weight\%, Oxygen 34.59 weight\% and small traces of Sulphur and Potassium. Other sample was used to analysis the presence of microorganism as the size of bacteria or virus varies from $100 \mathrm{~nm}$ to few micrometre size Ya-fen Wang et al 2010[21]. The sample filter paper was placed on LB-Agar solution in an autoclaved plate which acts like a growth medium for bacteria or virus and same was stored in incubator overnight at a temperature of $37^{\circ} \mathrm{C}$ and SEM of the same filter paper was carried out. The morphology of collected sample shows that particulates were completely rod-shaped particles which confirms that presence of bacteria Bacillus Fig. 7.b. Christine $\mathrm{G}$ et al 2016[22] and the elemental composition was found to be Carbon 37.30 weight $\%$, Nitrogen 2.04 weight \%, Oxygen 7.54 weight \% and small traces of Phosphorus and Sulphur

One sampling was carried out at BAS location in February and two sampling were carried out at DOM location in March and April were again used to study the presence of microorganism in the collected filter paper with SEM image technique and the same confirms the presence of microorganism with rod shaped morphology that is bacteria Bacillus Fig. 8.a-8.c and some particulates have cubical in shape with smooth surface area which may Sodium Chloride and the elemental composition at BAS location is found to be Carbon 44.29 weight\%, Nitrogen 4.51 weight\%, Oxygen 11.61 weight\%, Sodium 7.52 weight\% and small traces of Silicon, Phosphorus, Sulphur and the elemental composition DOM location March and April is Carbon 36.63 weight\%, Nitrogen 2.10 weight\%, Oxygen 6.50 weight\%, Sodium 5.32 weight\% and Chlorine 3.89 weight\% and Carbon 47.31 weight\%, Oxygen 25.05 weight\%, Nitrogen 10.32 weight\%, Sodium 3.12 weight\% and small traces of Silicon, Phosphorus, Sulphur, Chlorine and Calcium respectively. 
The morphology of sampling collected at DOM location in the month of May particulates in ambient air were spherical, irregular in shape with rough and smooth surface area Fig. 8.d. The elemental composition was found to be Carbon 31.31 weight\%, Oxygen 2.62 weight\% and small traces of Sulphur.

The morphology of sampling at DOM location in May and June were carried out shows that particulates are regular and irregular in shape with smooth and rough surface area Fig. 9.a-9. b and elemental composition Carbon 29.37 weight\%, Oxygen 2.68 weight\% and small traces of Sulphur and Carbon 33.91 weight $\%$, Oxygen 3.63 weight $\%$ and small traces of Nitrogen, Sodium and Sulphur.

The morphology of sampling at DCH location also shows the Particulates are regular and irregular in shape with smooth and rough surface area Fig. 9. c-9. d. which is in the month of June and July and the elemental composition Carbon 29.61 weight\%, Oxygen 1.06 weight\% and small traces of Aluminium and Sulphur and Carbon 29.33 weight\%, Oxygen 1.50 weight\% and small traces of Sulphur.

The particulate matter morphology in the study period was mainly found to be spherical shape with smooth surface area shows that $\mathrm{PM}_{1}$ source ambient air is mainly anthropogenic activities such as vehicular traffic, industrial activities, bio mass burning and irregular in shape with rough surface area identifies that source of $\mathrm{PM}_{1}$ is natural activities such as dust particles, resuspension of road dust, wind and the presence of bacteria in ambient air is also confirmed.

\section{Conclusion}

The $\mathrm{PM}_{1}$ mass concentration has been carried out at four different locations as follows Basavangudi (BAS), Hosur road (HOS), Domlur (DOM) and DC Halli (DCH). The highest mass concentration of $\mathrm{PM}_{1}$ was observed to be $68.64 \mu \mathrm{g} / \mathrm{m}^{3}$ at BAS and lower value of $20.16 \mu \mathrm{g} / \mathrm{m}^{3}$ at DOM. Meteorological parameters such as temperature, wind speed and relative humidity contributes significantly in the variation of PM1 mass concentration values as explained above. SEM-EDAX analysis for understanding the morphology and elemental composition of $\mathrm{PM}_{1}$ shows that particulate matter has both irregular and spherical shape with smooth and rough surface area. This indicates that source of $\mathrm{PM}_{1}$ is from both anthropogenic and natural activities. The micro-organism studies of few samples shows the presence of bacteria such as Bacillus and Bacillus pumilus which may have effect on human health which may lead to food poisoning, anthrax etc. EDAX analysis shows the presence of non-metals as well as metals and most abundant non-metal elements were Carbon, Oxygen, Nitrogen, Sulphur and Potassium. The traces of observed metals are Sodium and Calcium. These non-metals and metals may have direct or indirect effect on human health as the presence of higher weight\% of Carbon and Oxygen in ambient air may lead to lungs disorder.

\section{Declarations}

\section{Availability of data and material}


The data is available for the reference in the Excel format for the study period July 2018-july 2019

\section{Competing interests}

The authors does not have any competing interests for the manuscript

\section{Funding}

This research work is carried out with the help of TEQIP-III and Visvesvaraya Technological University (VTU)

\section{Authors' contributions}

Author and co-author have carried out the research work and preparation of manuscript together in the study period

\section{Acknowledgment}

The authors thank the management, Principal, Department of Bio-technology, Department of Mechanical Engineering of BMS College of Engineering

\section{References}

1. Wilson WE, Chow JC, Claiborn C, Fusheng W, Engelbrecht JJ, Watson G. Monitoring of Particulate Matter Outdoors. Chemosphere. 2002;49:1009-43.

2. Delfino RJ, Sioutas C, Malik S. Potential Role of Ultrafine Particles in Associations between Airborne Particle Mass and Cardiovascular Health. Environ Health Perspect. 2005;113:934-46.

3. Ramgolam K, Favez O, Cachier H, Gaudichet A, Marano F, Martinon L, Baeza-Squiban A. (2009). "Size-partitioning of an Urban Aerosol to Identify Particle Determinants Involved in the Proinflammatory Response Induced in Airway Epithelial Cells". Part Fibre Toxicol.6: 10, doi:10.1186/1743-8977-6-10.

4. Lu SL, Shao LY, Wu MH, Jiao Z. Mineralogical Characterization of Airborne Individual Particulates in Beijing PM10. J Environ Sci. 2006;18:90-5.

5. Adachi K, Tainosho Y. Characterization of Heavy Metal Particles Embedded in the Tire Dust. Environ Int. 2004;30:1009-17.

6. Marmur A, Park SK, Mulholland JA, Tolbert PE, Russell AG. Source Apportionment of PM2.5 in the South-eastern United States Using Receptor and Emissions-based Models: Conceptual Differences and Implications for Time Series Health Studies. AtmosEnviron. 2006;40:2533-51.

7. Jacob DJ, Winner DA. Effect of Climate Change on Air Quality. Atmos Environ. 2009;43:51-63. 
8. Spindler G, Brüggemann E, Gnauk T, Grüner A, Müller K, Herrmann H. A four-year size-Segregated Characterization Study of Particles PM10, PM2.5 and PM1 Depending on Air Mass Origin at Melpitz. Atmos Environ. 2010;44:164-73.

9. Fransen M, Pérodin J, Hada J, He X, Sapkota A. Impact of Vehicular Strike on Particulate Matter Air Quality: Results from a Natural Intervention Study in Kathmandu Valley. Environ Res. 2012;122:52-7.

10. Aryal RK, Lee BK, Karki R, Gurung A, Baral B, Byeon SH. “Dynamics of PM2.5 Concentrations in Kathmandu Valley”, Nepal. J Hazard Mater. 2009;168:732-8.

11. Pope CA, Dockery DW. Health Effects of Fine Particulate Air Pollution: Lines that Connect. J Air Waste Manage Assoc. 2006;56:709-688.

12. https://transport.karnataka.gov.in/.

13. http://dcmsme.gov.in/dips/Bangalore\%20Urban\%20District.pdf.

14. https://data.gov.in/resources/national-ambient-air-quality-standards-naaqs.

15. http://kspcb.gov.in/ambient_air_quality.html.

16. koulouri E, grivas $\mathrm{G}$, gerasopoulos $\mathrm{E}$, chaloulakou $\mathrm{E}$, mihalopoulos $\mathrm{N}, \mathrm{N}$. spyrelli. study of sizesegregated particle (pm1, pm2.5, pm10) concentrations over Greece. Global NEST Journal. 2008;10(2):132-9.

17. Glenn E, Shaw. "Sun photometry" (1970). Geophysical Institute University of Alaska Fairbanks, Alaska 99701.

18. Mirjana, Tasić. Branislava Đurić-Stanojević, Slavica Rajšić, Zoran Mijić, Velibor Novaković "PhysicoChemical Characterization of $\mathrm{PM}_{10}$ and $\mathrm{PM}_{2.5}$ in the Belgrade Urban Area". Acta Chim Slov. 2006;53:401-5.

19. Pipal AS, Jan R, Satsangi PG, Tiwari S, Ajay Taneja. "Study of Surface Morphology, Elemental Composition and Origin of Atmospheric Aerosols (PM2.5 and PM10) over Agra, India (2014). Aerosol and Air Quality Research, 14: 1685-1700.

20. $10.1038 /$ srep 19778

Flavien Pillet, Cécile Formosa-Dague, H, Baaziz. Etienne Dague \& MariePierre Rols "Cell wall as a target for bacteria inactivation by pulsed electric fields". Scientific Reports 2006 | 6:19778 | DOI: 10.1038/srep19778.

21. Ya-FenWang. Che-HsuWang, Kai-LinHsu.(2010)“Size and seasonal distributions of airborne bioaerosols in commuting trains". Atmospheric Environment44,4331-4338.

22. $10.1038 /$ srep26516

Christine G, Golding LL, Lamboo DR, Beniac, Timothy F, Booth. "The scanning electron microscope in microbiology and diagnosis of infectious disease". Scientific Reports | 6:26516 | DOI:

$10.1038 /$ srep26516.

\section{Figures}




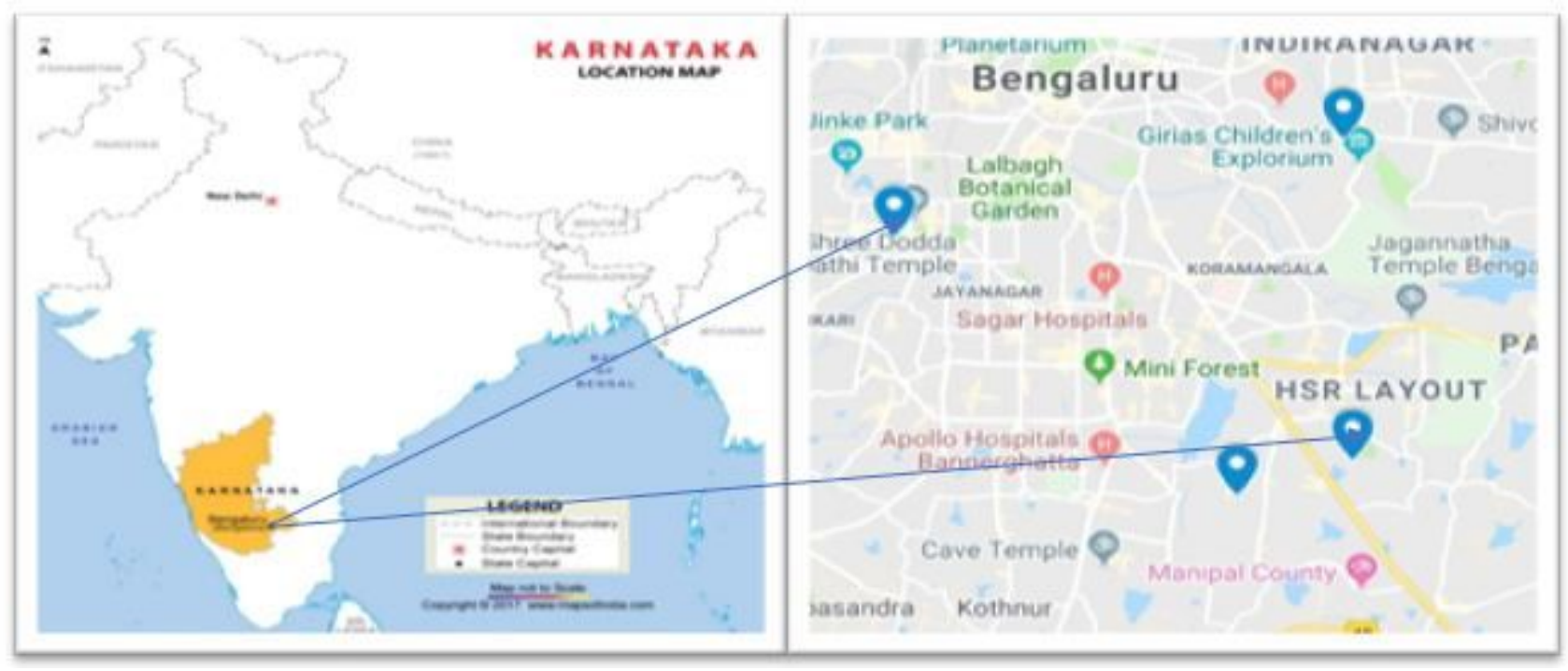

Figure 1

PM1 sampling locations in Bengaluru

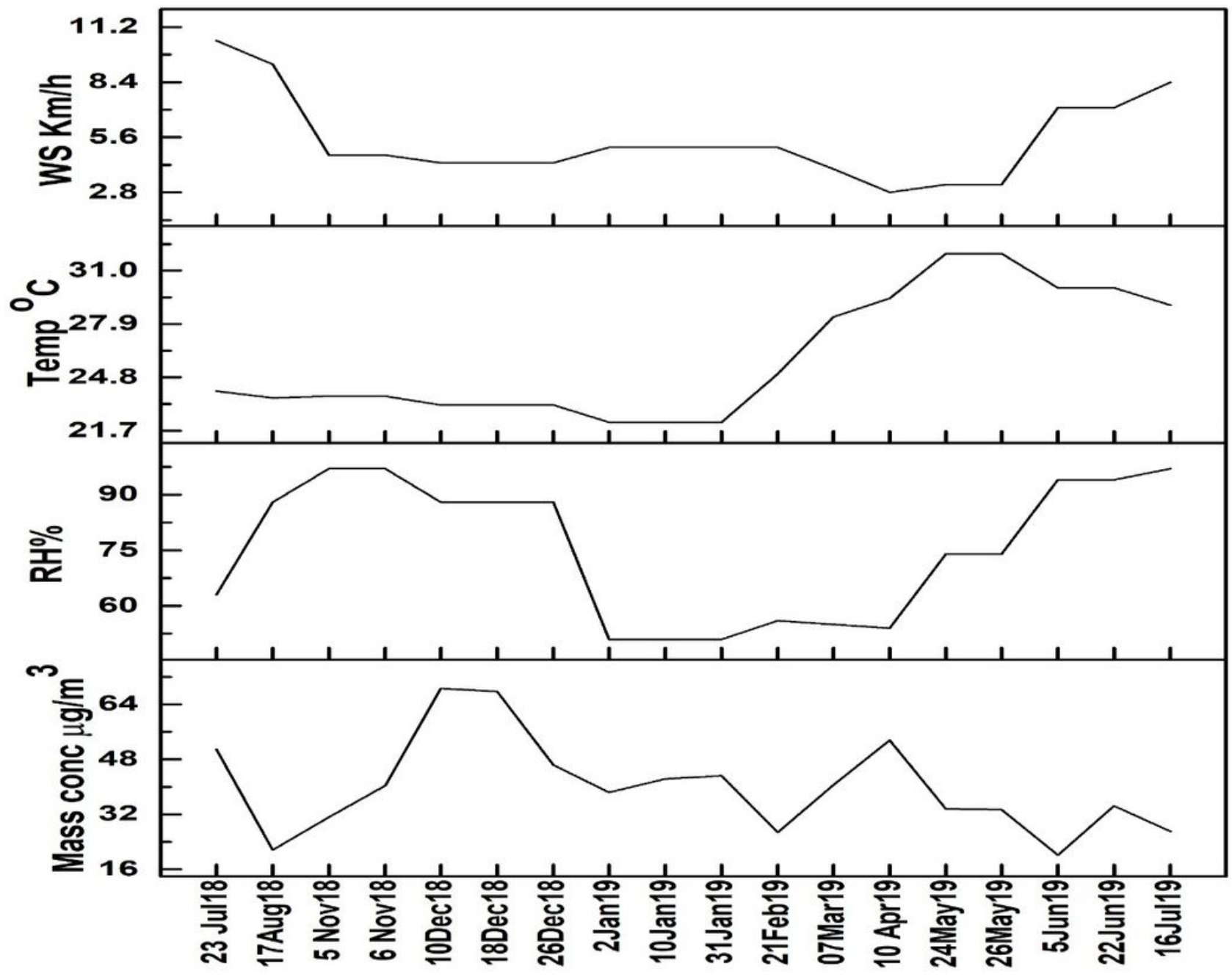


Figure 2

variation PM1 mass concentration with temperature, wind speed, season and relative humidity
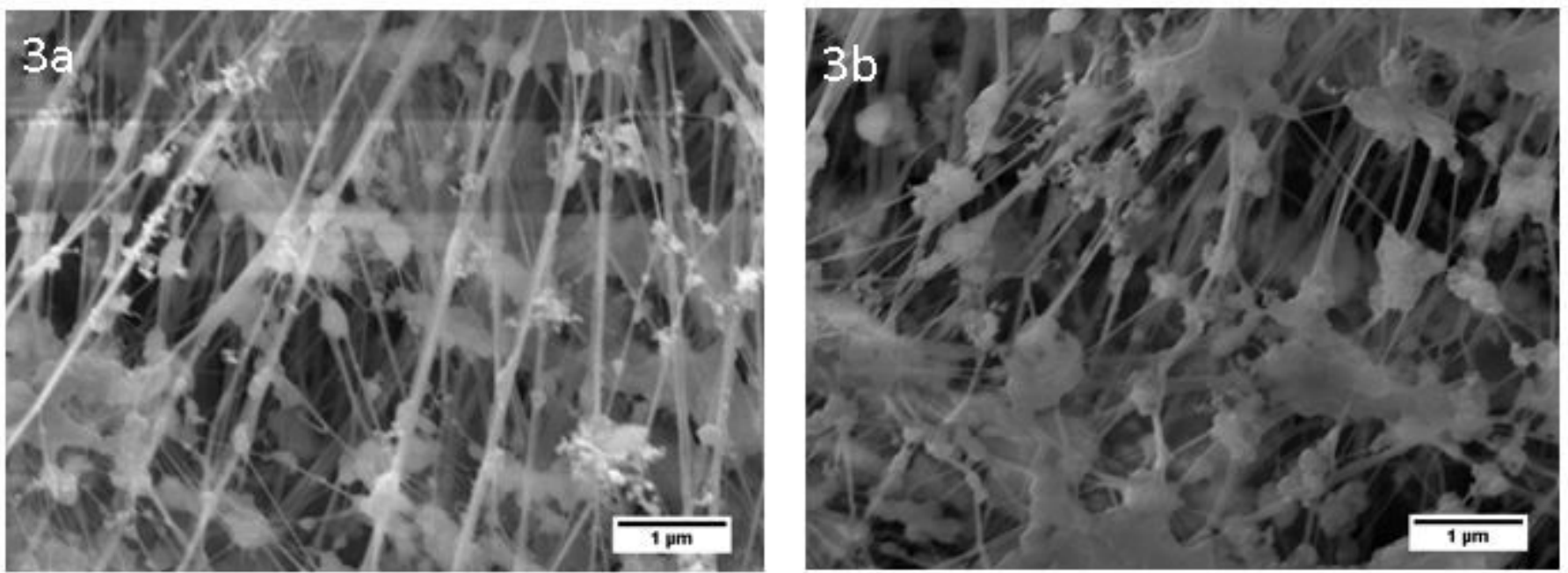

\section{Figure 3}

3a. SEM image of PM1 at BAS 3b. SEM PM1 image at HOS
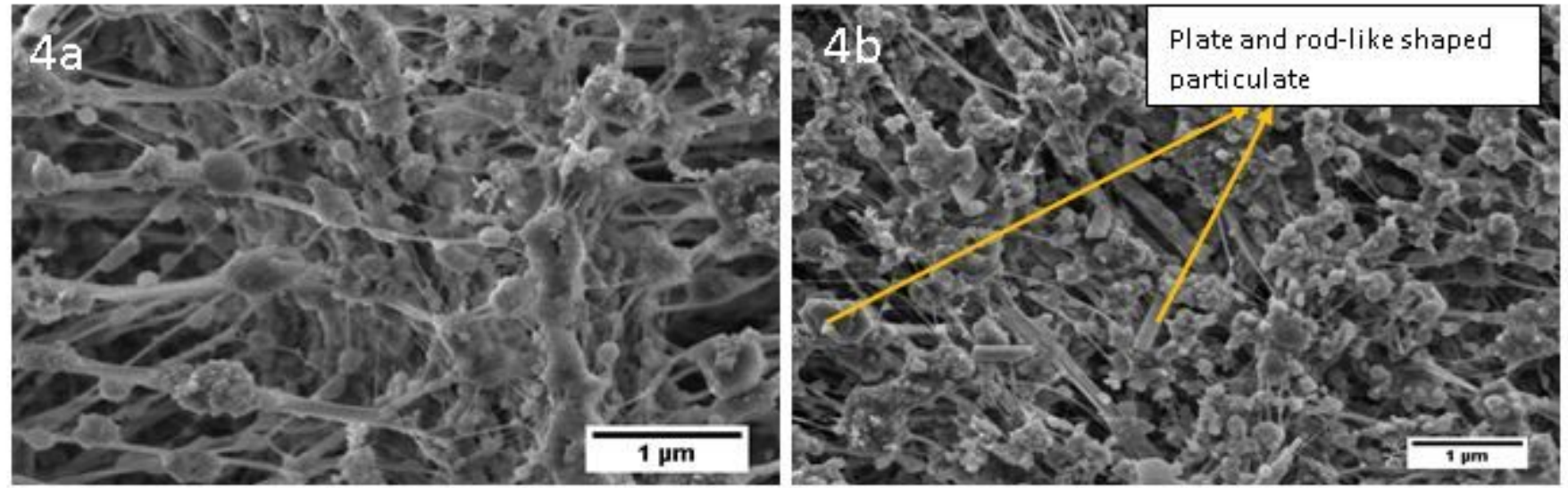

Figure 4

4 a. SEM image of PM1 at HOS a day before Diwali 4. b. SEM image on the day of Diwali 

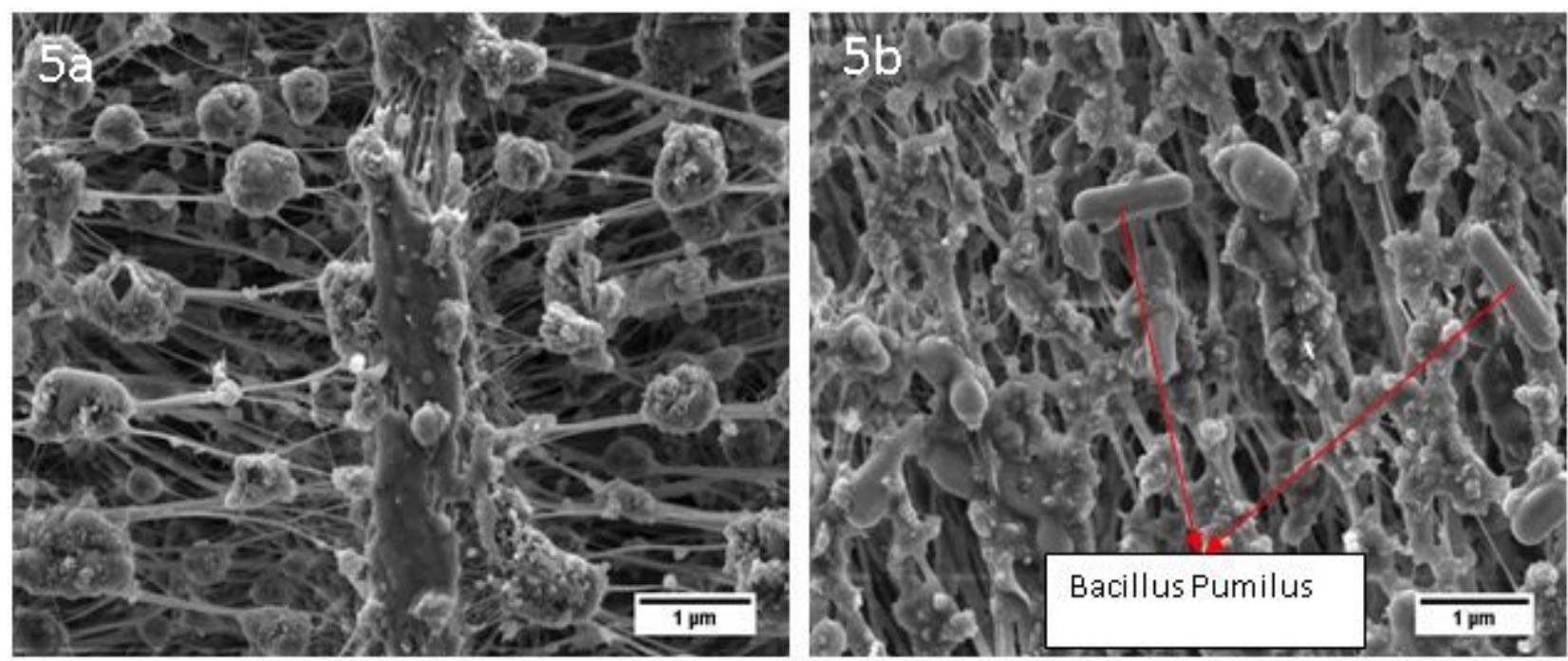

Figure 5

5a. SEM image of PM1 at BAS 5b. SEM image of PM1at HOS
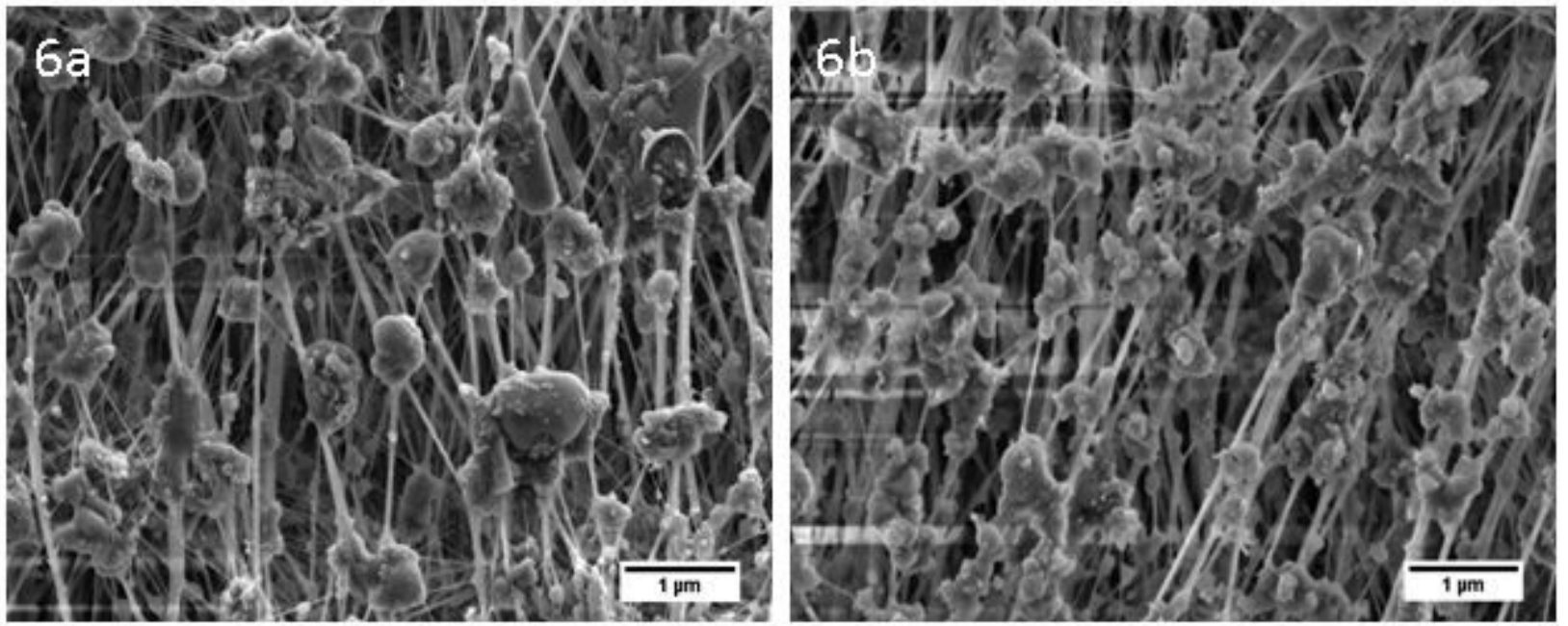

Figure 6

6a. SEM image of PM1 sample collected at DOM 6b. SEM image of PM1 sample collected at DOM 

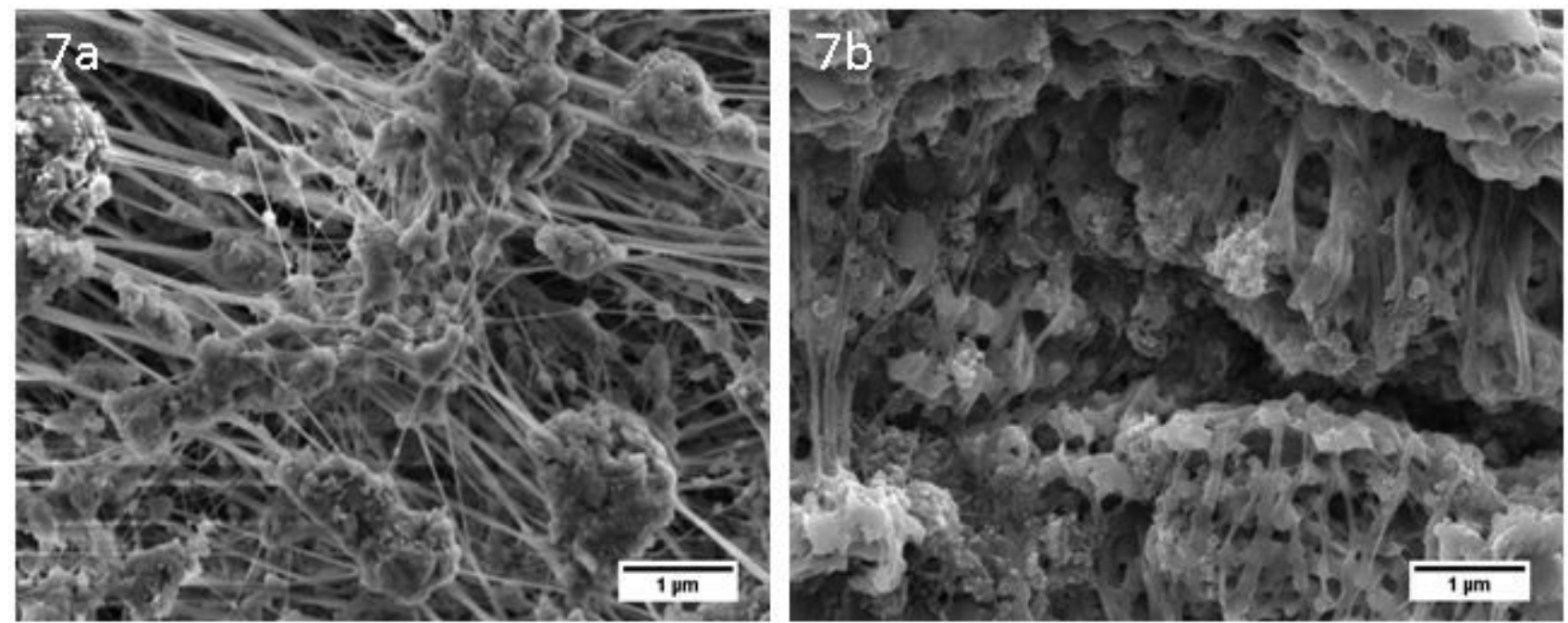

Figure 7

7a. SEM image of PM1 sample collected at BAS 7b. SEM image of PM1 sample collected at BAS
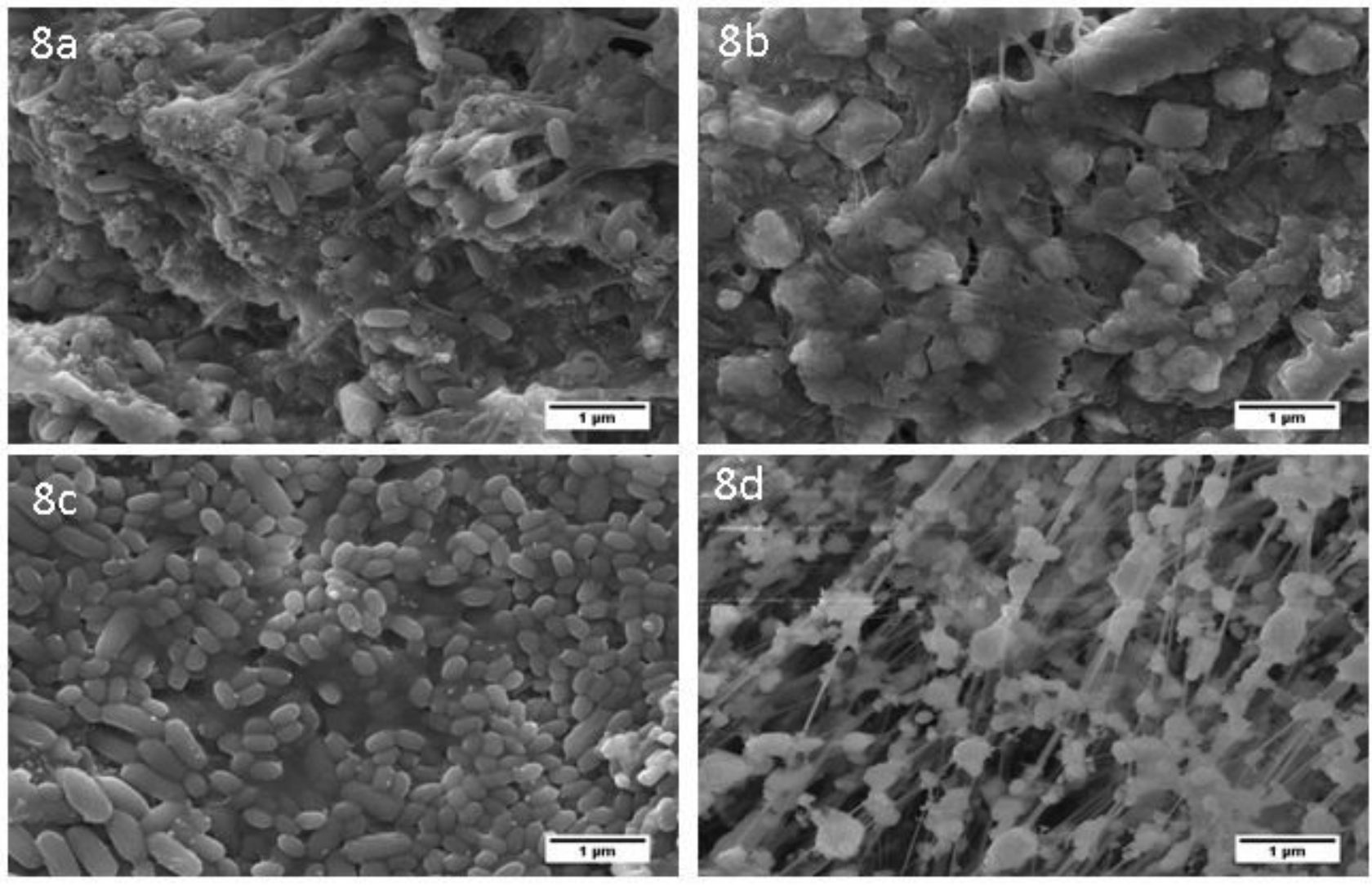

\section{Figure 8}

a.SEM image of PM1 sample collected at BAS which is used for microorganism studies and Fig8b-8d SEM imageof PM1sample collectedat DOM in February, March and April respectively. 

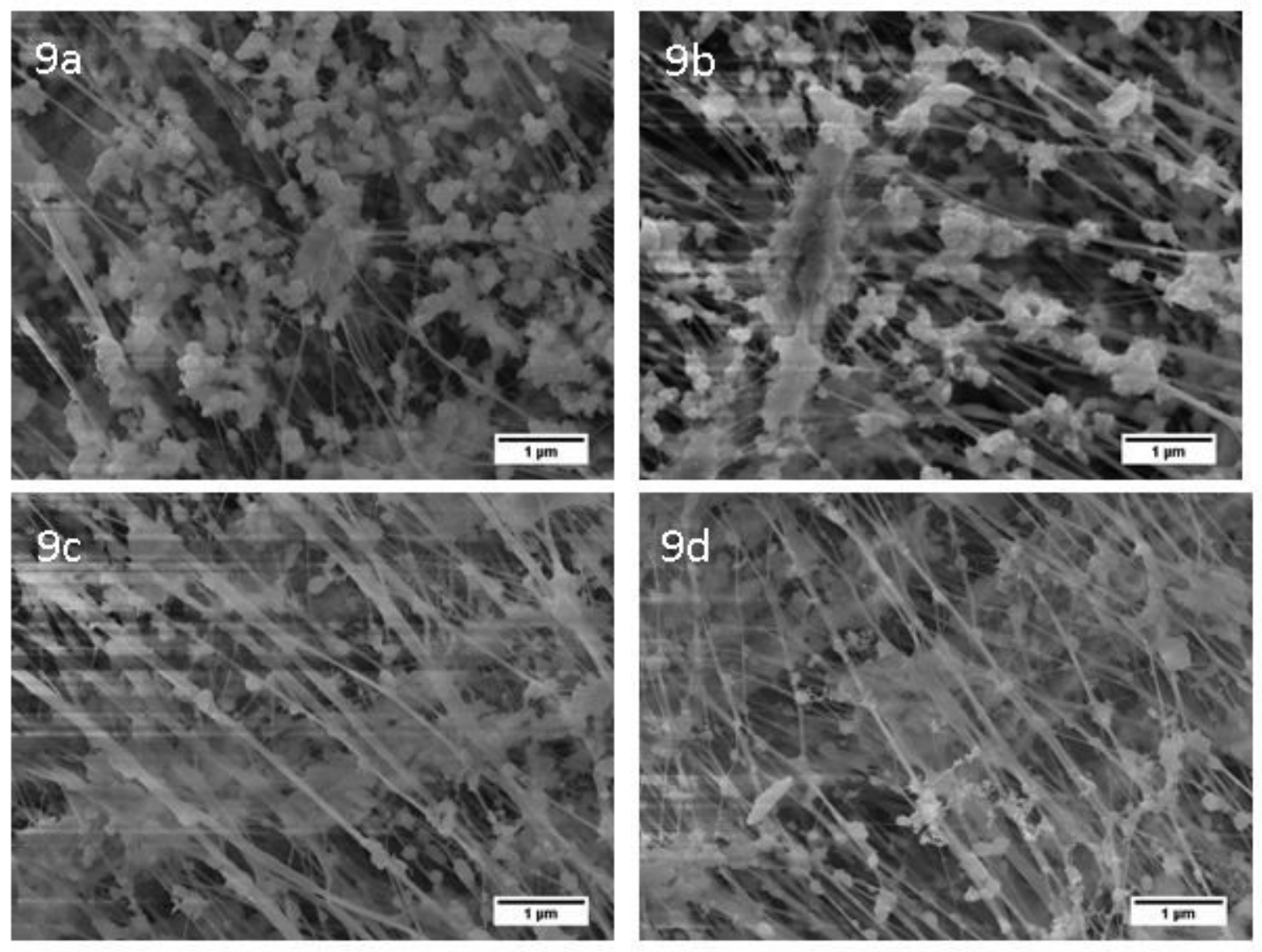

Figure 9

9a-9b. SEM image PM1 sample collected at DOM of May and June month and Fig. 9c-9d SEM image PM1 sample collectedat DCH of June and July

\section{Supplementary Files}

This is a list of supplementary files associated with this preprint. Click to download.

- PM1datasheet1.xlsx 